------ Raf. J. Sci., Vol. 24, No.6 pp. 23-36, 2013------

\title{
Isolation of Latent Matrix Metallo Proteinase-1 (Latent Collagenase-1) from Serum and Synovial Fluid of Rheumatoid Arthritis Patient
}

\author{
Zahraa M. Hamoudatt \\ Department of Chemistry \\ Collage of Science \\ Mosul University \\ Layla A. Mustafa
}

(Received 21/10/2012 ; Accepted 27/5/2013)

\begin{abstract}
This study included the isolation of the enzyme Matrix Metalloprotrinase-1 (MMP-1; Collagenase-1) from serum of healthy individual and synovial fluid (SF) of a patient with rheumatoid arthritis using different techniques.

After precipitation of proteins using saturated ammonium sulfate, two porteinous components had been isolated by gel filtration chromatography. It was found that only the first peak has high activity of latent-MMP-1. The apparent molecular weights of MMP-1 in serum and SF using gel filtration chromatography was found to be (47752 \pm 816 and $48194 \pm 707)$ dalton respectively.

High performance liquid chromatography (HPLC) was used to show the extent of purity. The main maximum of the enzyme from serum and SF appeared at retention times (1.652 and 1.65) minutes respectively compared with the retention time of standard enzyme at (1.571) minutes. The approximate molecular weight of latent-MMP-1 by HPLC technique, in serum and SF were found (48067 and 48033) dalton respectively.

The study included, also, the effect of some material compounds on the activity of latentMMP-1. The results revealed that the addition of ethylene diamine tetra acetic acid (EDTA), 2,4-dinitrophenol, sodium azide, potassium oxalate, mercaptoethanol (MEH), glutathione (GSH), cystein and healthy human serum decreased the activity of latent-MMP-1, while the addition of $\mathrm{NaCl}, \mathrm{MgSO}_{4}, \mathrm{CoCl}_{2}, \mathrm{CaCl}_{2}, \mathrm{CuSO}_{4}, \mathrm{ZnSO}_{4}, \mathrm{HgCl}_{2}$ and pepsin increases the activity of enzyme.
\end{abstract}

Keywords: Matrix metalloproteinase-1, collagenase-1, Rheumatoid arthritis. 


\section{عزل أنزم الميتالوبروتينيز -1 -الكالن (الكولاجينيز -1 - الكامن) aن المطل والملال الزليلي المربض مصلب بالتهلب الفاليل الرخوي}

\section{المانهص}

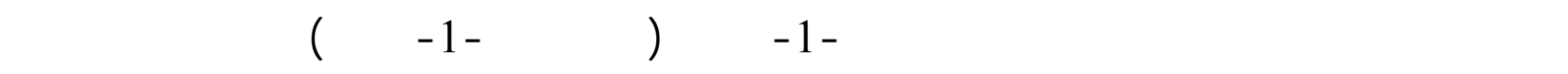
سليم ومن للسالل الزليلي لمريض مصلب بالتهلب المفاصل الرثوي بلستخدلم ققنيت مختلفة. وقد فصلت حزيتل حزمتين

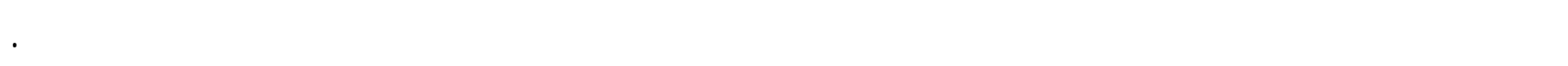
لظٔهرت حزمة ولحة فتط فعالية عالية لأنزيم الميتالوبروتينيز - 1 -الكلمن.

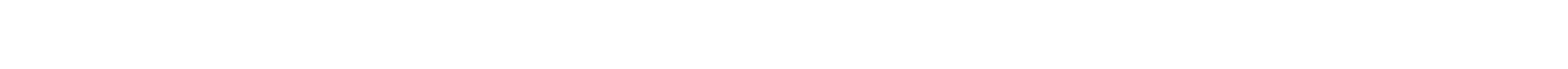
(47752

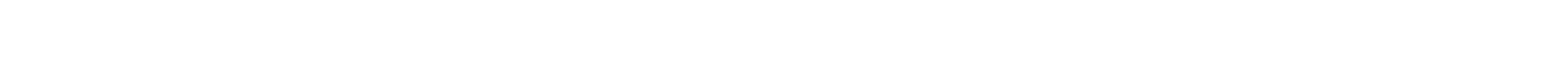

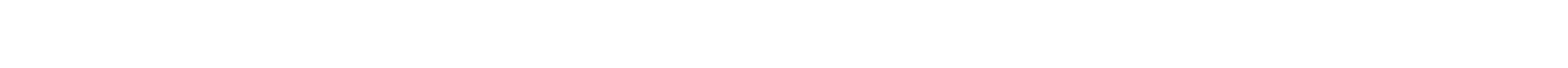

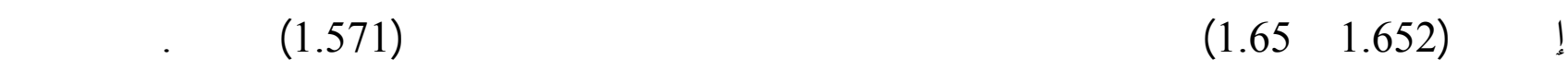

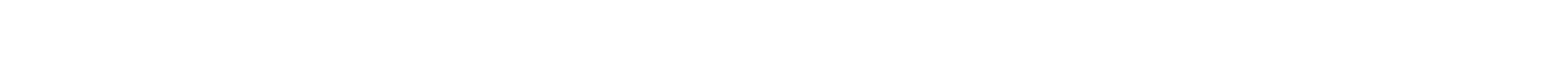

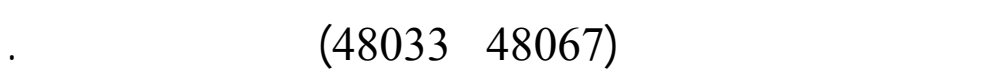

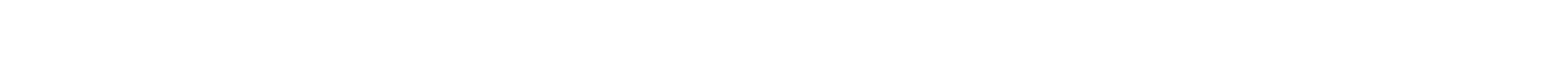

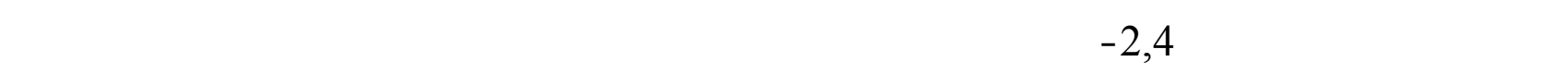

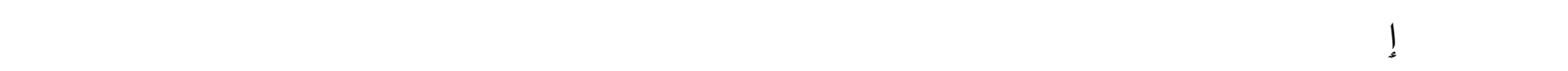
كلوريد الصويوم والكللسيوم والكوبالت والزئبق وكبريتات المغنيسيوم والنحلس والخارصين والببسين تؤوي إله زيادة فعالية الأنزيم.

الكاملت الدالة: الفزيم الميتالو بروتينيز -1 -، الكولاجينيز -1 -، التهلب المفاصل الرثوي.

\section{INTRODUCTION}

Rheumatoid arthritis (RA) is a systemic inflammatory disease of unknown etiology (Scherer et al., 2010). It usually causes damage and disability of patient's small joints by activity of the chronic and acute inflammation which is the major complication for this proteolytic disease (Yang and Wang, 2011). The destruction of cartilage joint and bone in RA is mediated by abnormal release of proteolytic enzymes which are stimulated by persistent inflammation of synovial tissue such as the matrix metalloproteinases (MMPs) (Chen et al., 2012; Scherer et al., 2010). 
Matrix metalloproteinases are family of zinc metallo endopeptidase that degrade all components of extra cellular matrix (ECM) (Philips et al., 2011; Fields et al., 2000; Maeda et al., 1995). Interstitial collagenase-1 (collagenase-1) also known as matrix metalloproteinase-1 (E. C. 3. 4. 24. 7; MMP-1) is a member of MMPs family, which cleaves collagens type I, II and III, and resulting two triple helical fragments representing $25 \%$ and $75 \%$ of the original molecule (Daboor et al., 2012; Fasciglion et al., 2012; Fields et al., 2000; Maeda et al., 1995). Collagen is a major fibrous element of skin, bones, tends cartilage, blood vessels and teeth which are found in all multi-cellular animals (Jain and Jain, 2010). Collagens are extremely stable and highly resist to degradation by all proteinases except for MMPs (Polyakova et al., 2011). MMPs have been implicated in several physiological and pathological processes such as, skeletal growth and remodeling, wound healing, cancer, arthritis and multiple sclerosis (Fasciglion et al., 2012; Leit et al., 2009; Erdam et al., 2002).

In synovial joints, MMPs are mainly secreted by fibroblasts, macrophages and chondriocytes (Chen et al., 2012). Synovial fluid (SF) of RA patients showed about thirty times of collagenase and elastase activity compared to normal, which degrade the joint tissues (Sandya et al., 2009). MMPs are synthesized in an inactive (latent) form called zymogene or pro-MMPs. These latents of MMPs require an activation step before they become able to cleave ECM components (Sandya et al., 2009; Beurden and Hoff, 2005).

Latency of collagenase is removed to form the active enzyme by proteolytic enzymes such as trypsin and non proteolytic agents such as chatropic salts and organo mercurial. The conversion of latent enzyme to its active enzyme is accompanied by a decrease in its molecular weight of about (10-20) kilo dalton (Leite et al., 2009; Meada et al., 1995; Smith et al., 1989). The difference in the molecular weight of MMPs is depend on their type (serine or metalloproteinase) and their source (animal or microbial) (Daboor et al., 2010). The activity of MMPs is regulated by several types of inhibitors called tissue inhibitor of metalloproteinases (TIMPs) (Sandya et al., 2009; Peak et al., 2005).

This study is a primary attempt to bridge the gap of knowledge about latent MMP-1 by studying its activity, purification, approximate molecular weight and the effect of some compounds on its activity.

\section{Collection of blood and synovial fluid}

MATERIAL AND METHODS

\section{A-Blood Serum}

A fresh human serum was obtained from one healthy non smoker male volunteer attending the blood bank in Nineveh Governorate, aged 38 years. Serum was kept in clean dry tube at $-20^{\circ} \mathrm{C}$ and used as a source for the enzyme isolation (Tietz, 1994).

\section{B- Synovial Fluid}

Synovial fluid was obtained from knee joint of non smoker male patient with RA attending the rheumatology outpatient clinic at Ibin- Siena teaching hospital, aged 45 year. He has met the American College of Rheumatology (ACR) and the European League Against Rheumatism (EULAR) criteria for diagnosis of RA (Aletaha et al., 2010; Arnett et al., 1988) 
and treated with non-steroidal-anti-inflammatory drugs (SIDEs), disease modifying antirheumatic drugs non-steroidal inflammatory drugs (DMARDs), and he was not affected by other diseases. The SF was kept in a clean dry tube at $-20^{\circ} \mathrm{C}$ and used as a source for the enzyme isolation (Matsumoto et al., 2006).

\section{Determination of Total Protein Concentration}

Total protein concentration in serum and SF was determined in each isolation's step using bovine serum albumin as a standard (Holme and Peck, 1988) according to the modified lowery method (Schacterle and Pollack, 1973).

\section{Determination of latent -MMP-1 Activity}

Latent-MMP-1 activity in serum and SF was measured in each isolation's step using a commercial Human MMP-1 ELISA kit (Kim et al., 2011; Peak et al., 2005; Erdam et al., 2002; Maeda et al., 1995), kindly donated by Ray Bio United Kingdom. This assay employs an antibody specific for human MMP-1 coated on a 96 well plate. Standards and samples were pipetted into the wells and MMP-1 present in a sample was bound to the wells by the immobilized anti body. The wells were washed and the biotinylated anti-human MMP-1 antibody was added. After washing away the unbound biotinylated antibody, HRP-Conjugated Sterptavidin was pipetted to the wells. The wells were again washed and a 3, 3', 5, 5'-tetra methyl benzidine (TMB) substrate solution was added to the wells and a color developed in proportion to the amount of MMP-1 bound. Sulfuric acid was used to stop the reaction. the color was changed from blue to yellow and the color intensity was measured spectrophotometrically at $450 \mathrm{~nm}$. Recombinant human MMP-1 was used as a standard. This kit has a limit of detection of $8 \mathrm{pg} / \mathrm{ml}$. Samples of serum and SF were diluted with diluents buffer 1:20 and 1:40 respectively.

\section{Protein Isolation}

\section{A- Fraction of Latent MMP-1}

Proteins of serum and SF were precipitated by saturation with ammonium sulfate or by protein salting out (Robyt and White, 1987; Dioxin and Weeb, 1961). The samples of serum $(30 \mathrm{ml})$ and SF $(21 \mathrm{ml})$ were brought to $75 \%$ saturation with ammonium sulfate. The addition of ammonium sulfate was gradual, a small amount was added and allowed to dissolve before making further additions. The mixtures were stirred by electrical stirror at $4^{\circ} \mathrm{C}$ for 60 minutes, then left overnight in the refrigerator. The precipitate formed was then separated by refrigerated centrifuge at $10000 \mathrm{xg}$ for 30 minutes.

\section{B- Dialysis}

the precipitated protein solution $(22 \mathrm{ml})$ from serum and $(15 \mathrm{ml})$ from SF desalted by dialysis method using a $25 \mathrm{~mm}$ cellulose membrane dialysis tube which is placed in a container containing sodium bicarbonate $0.1 \mathrm{M}$. Ammonium sulfate desalting was carried out three consecutive times (48 hours for each time) (Robyt and White, 1987).

\section{C- Isolation and Partial Purification of Latent-MMP-1}

Gel filtration chromatography technique was used for isolation and partial purification of latent-MMP-1 in serum and SF (Andrews 1965), using column $(1.21 \times 110 \mathrm{~cm})$ which contains sephadex G-75 gel to $(106 \mathrm{~cm})$ height. The fractions were collected $(2 \mathrm{ml} / 5 \mathrm{~min})$ at a flow rate of $24 \mathrm{ml} /$ hour, using a distilled water as eluent solution. Approximate molecular weight of the 
partially purified latent-MMP-1 was determined from its elution volume under the same conditions of known molecular weight.

\section{D- Freeze- Drying (Lyophilization) Technique}

The porteinous fraction which was obtained from ammonium sulfate precipitation method and gel filtration column was dried by lyophilization technique to obtain solid or concentrated protein solution. The porteinous compound was kept in a deep freeze at $-20^{\circ} \mathrm{C}$ in a tight sample tube to be used for further investigations.

\section{- Reveres Phase -High- Performance Liquid Chromatography (RP-HPLC)}

The study included using RP-HPLC technique (Shimadzu System) employing the column $\mathrm{C}_{8}$ (RP8) which contains n-alkyl silica as a solid phase. Acetonitril $90 \%$ solution (90:10; acetonitril: distilled water) was used as a mobile phase, at a flow rate of $2 \mathrm{ml} / \mathrm{minute}$ with UVdetector set at $280 \mathrm{~nm}$ (Carr, 2002). A sample from gel filtration (peak A) for serum and synovial fluid as a source of latent MMP-1 and known molecular weight proteins (as standards) were applied. This analysis was performed in the state Company for Drug Industries and Medical Appliances in Nineveh.

\section{RESULTS AND DISCUSSION}

The results of partial purification of MMP-1 from serum and SF are shown in Table (1 and 2).

The data in Table 1 and 2 show that the recovery of MMP-1 increased in peak A $154.89 \%$ and $189 \%$ than crude extracts of serum and SF respectively. The increased enzyme activity in SF of patient with RA to about 5 times more than the enzyme activity in serum of healthy due to the presence of cytokines derived from inflammatory cells such as interleukin-1, which can modulate the amount of collagenase synthesized. This result is similar to the finding of several studies (Kim et al., 2011; Peak et al., 2005; Tchetverikov et al., 2005; Maeda et al., 1995).

Table 1: Partial purification of latent-MMP-1 from serum healthy individual

\begin{tabular}{|c|c|c|c|c|c|c|}
\hline Steps & $\begin{array}{c}\text { Volume } \\
\text { (ml) }\end{array}$ & $\begin{array}{c}\text { Protein } \\
\text { conc. } \\
\mathbf{( m g / m l )}\end{array}$ & $\begin{array}{c}\text { Total latent } \\
\text { MMP-1 activity } \\
\text { (ng/ml) }\end{array}$ & $\begin{array}{c}\text { Total specific } \\
\text { activity of } \\
\text { latent-MMP-1 } \\
\text { (ng/mg) }\end{array}$ & $\begin{array}{c}\text { Purification } \\
\text { fold }\end{array}$ & $\begin{array}{c}\text { Recovery } \\
\text { \% }\end{array}$ \\
\hline Serum & 30 & 1470.9 & 3321 & 2.258 & 1 & 100 \\
\hline $\begin{array}{c}\text { After } \\
\text { precipitation }\end{array}$ & 22 & 234.74 & 3090.56 & 13.165 & 6 & 93.06 \\
\hline After Dialysis & 26 & 235.04 & 3494.14 & 14.866 & 7 & 105.21 \\
\hline $\begin{array}{c}\text { Gel filtration } \\
\text { sephadex (G-75) } \\
\text { peak (A) }\end{array}$ & 31.2 & 58.968 & 5143.94 & 87.232 & 39 & 154.89 \\
\hline $\begin{array}{c}\text { Gel filtration } \\
\text { sephadex (G-75) } \\
\text { peak (B) }\end{array}$ & 27.1 & 76.15 & 1722.21 & 22.615 & 10 & 51.858 \\
\hline
\end{tabular}


Table 2: Partial purification of latent-MMP-1 from SF of rheumatoid arthritis patient

\begin{tabular}{|c|c|c|c|c|c|c|}
\hline Steps & $\begin{array}{c}\text { Volume } \\
\text { (ml) }\end{array}$ & $\begin{array}{c}\text { Protein } \\
\text { conc. } \\
(\mathbf{m g} / \mathbf{m l})\end{array}$ & $\begin{array}{c}\text { Total latent } \\
\text { MMP-1 activity } \\
\text { (ng/ml) }\end{array}$ & $\begin{array}{c}\text { Total specific } \\
\text { activity of } \\
\text { latent-MMP-1 } \\
\text { (ng/mg) }\end{array}$ & $\begin{array}{c}\text { Purification } \\
\text { fold }\end{array}$ & $\begin{array}{c}\text { Recovery } \\
\%\end{array}$ \\
\hline Synovial fluid & 21 & 483 & 11036.97 & 22.85 & 1 & 100 \\
\hline $\begin{array}{c}\text { After } \\
\text { precipitation }\end{array}$ & 15 & 149.1 & 9180 & 61.569 & 3 & 83.18 \\
\hline $\begin{array}{c}\text { After Dialysis } \\
\text { Gel filtration } \\
\text { sephadex } \\
\text { (G-75) } \\
\text { peak (A) }\end{array}$ & 20 & 165.6 & 10354.6 & 62.528 & 3 & 93.82 \\
\hline $\begin{array}{c}\text { Gel filtration } \\
\text { sephadex } \\
\text { (G-75) } \\
\text { peak (B) }\end{array}$ & 30.2 & 43.49 & 4990.25 & 114.75 & 58 & 189 \\
\hline
\end{tabular}

\section{- Fractionation of Total Protein}

Fractionation of total proteins, resulting from ammonium sulfate saturation after dialysis and lyophilization for serum and SF, by gel filtration chromatography produced two porteinous compounds A and B (Fig.1 and 2). Peak A was obtained with high MMP-1 activity (164.87 and 737.12) $\mathrm{ng} / \mathrm{ml}$ from serum and SF respectively while peak B with low MMP-1 activity in both serum and SF was neglected at this stage. 


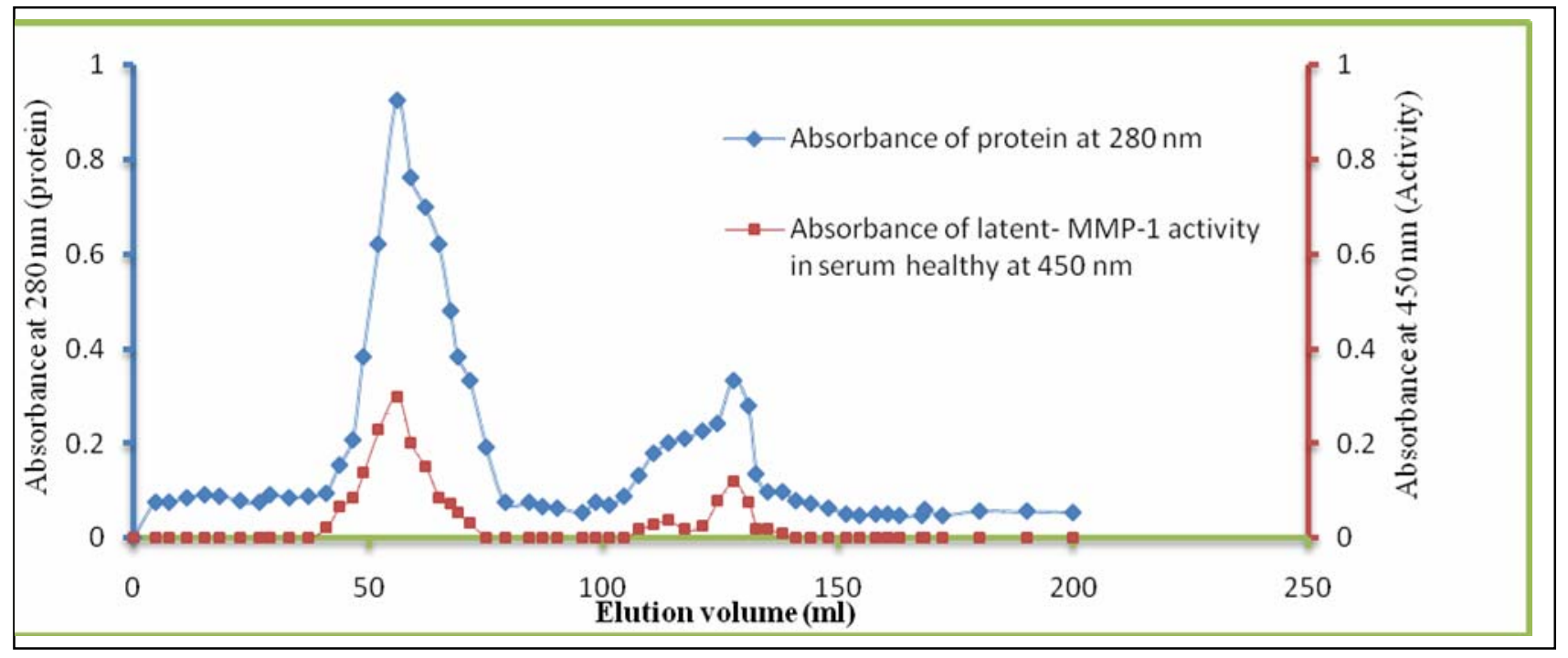

Fig. 1: Elution profile of latent-MMP-1 in serum healthy using G-75, column (1.21 x 110 cm) to height $(106 \mathrm{~cm})$. Each fraction was $(2 \mathrm{ml} / 5$ minutes) at a flow rate of 24 ml/hour

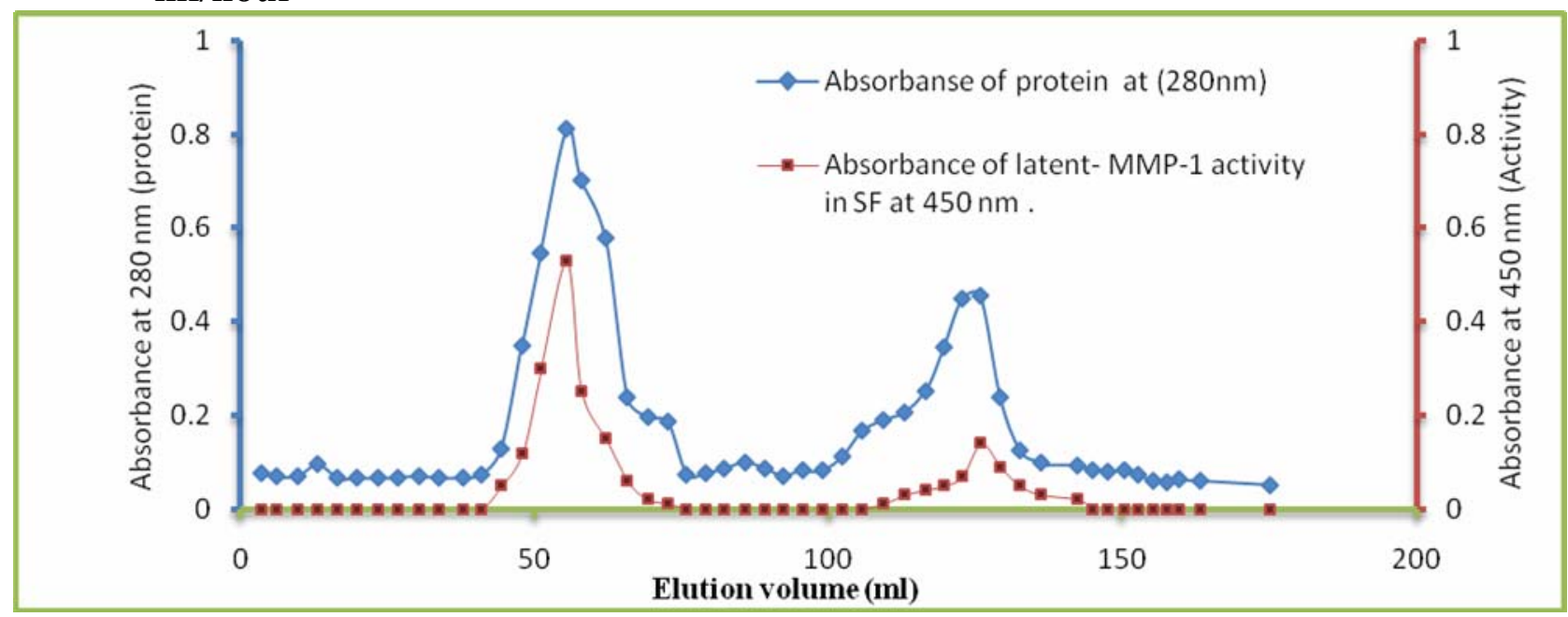

Fig. 2: Elution profile of latent-MMP-1 in SF of RA patient using G-75, column (1.21 $x$ $110 \mathrm{~cm})$ to height $(106 \mathrm{~cm})$. Each fraction was $(2 \mathrm{ml} / 5 \mathrm{minutes})$ at a flow rate of 24 $\mathrm{ml} /$ hour

The apparent molecular weight (MWt.) of the partially purified latent-MMP-1 peak A in serum and SF was determined by gel filtration (Andrews, 1965) and found to be in the range of $(47752 \pm 816)$ and $(48194 \pm 707)$ dalton respectively by comparing them with known molecular weight proteins which are listed in Table (3) and Fig. (3). These results were in good agreement with other findings (Vater et al., 1978). 
Table 3: Elution volume of known molecular weight materials and samples from (serum and SF) using G-75

\begin{tabular}{|l|c|c|}
\hline Material & Molecular weight (dalton) & Elution volume (ml) \\
\hline BSA & 67000 & 40 \\
\hline$\alpha$-amylase & 58000 & 46 \\
\hline Egg albumin & 45000 & 58 \\
\hline Pepsin & 36000 & 70 \\
\hline Latent-MMP-1/Serum & 47752 & 55.6 \\
\hline Latent-MMP-1/SF & 48194 & 55.1 \\
\hline
\end{tabular}

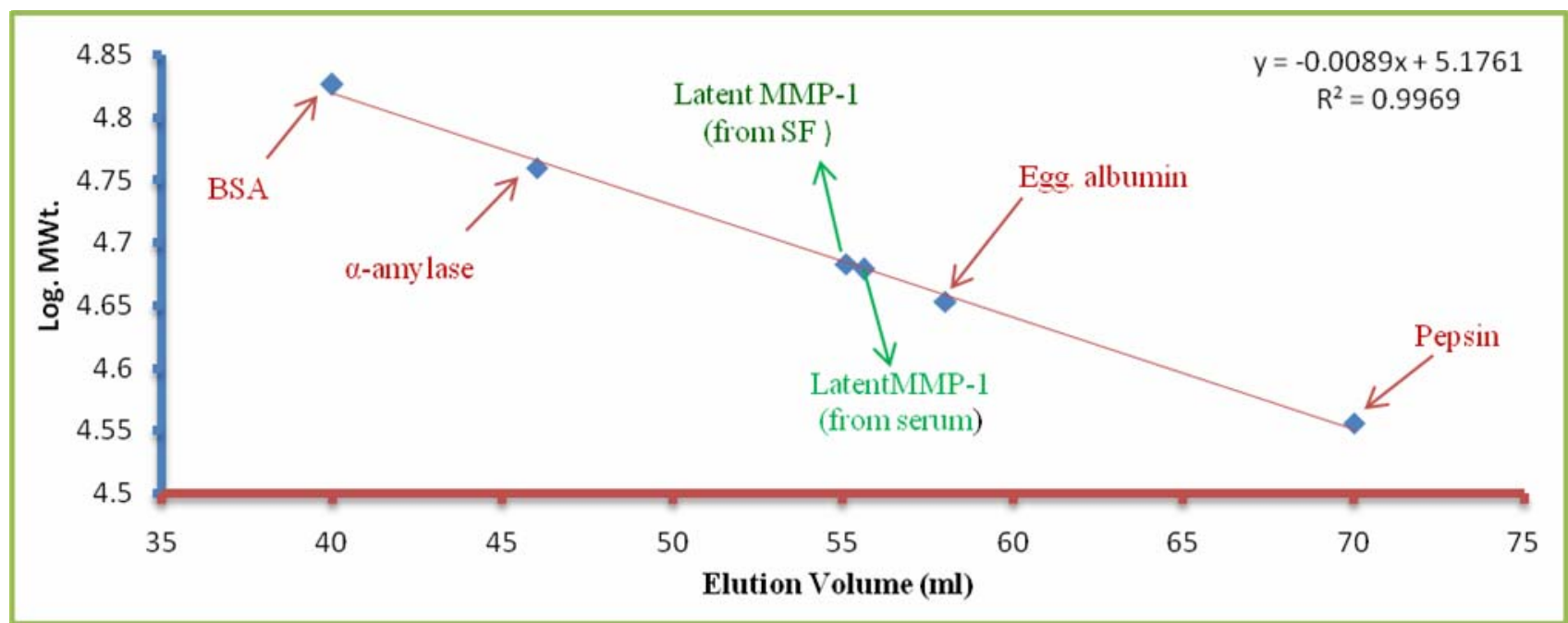

Fig. 3: Standard curve for determining the molecular weight (MWt.) of Latent-MMP-1 from serum and synovial fluid using Sephadex G -75

\section{- Reveres Phase High- Performance Liquid Chromatography (RP-HPLC)}

Reveres Phase High- Performance Liquid Chromatography technique (RP-HPLC) was used to check the purity of the isolated latent matrix metalloproteinase-1 (peak A) from serum and synovial fluid.

The results in Fig. (4 and 5) show a sharp peak for serum and SF manifested with retention times (RT) (1.652 and 1.65) minutes respectively. This technique was also used to determine the approximate molecular weight of peak (A) as a source of latent MMP-1 from serum and SF by comparing them with the known molecular weight proteins which were listed in Fig. (6, 7,8 and 9).

The results show a sharp peak appearance of serum and SF between retention times of standards egg albumin and latent- MMP-1 which indicates that the molecular weight of enzyme in serum and SF were found (48067 and 48033) dalton respectively. 
These results are in good agreement with other findings (Vater et al., 1978; Maeda et al., 1995; Daboor et al., 2012 ). This enzyme is converted by trypsin to an active form with a molecular weight of about (33000) dalton. When the enzyme is mixed with an inhibitor the active enzyme formed an inactive complex again with molecular weight between (4500049000) dalton (Vater et al., 1978).

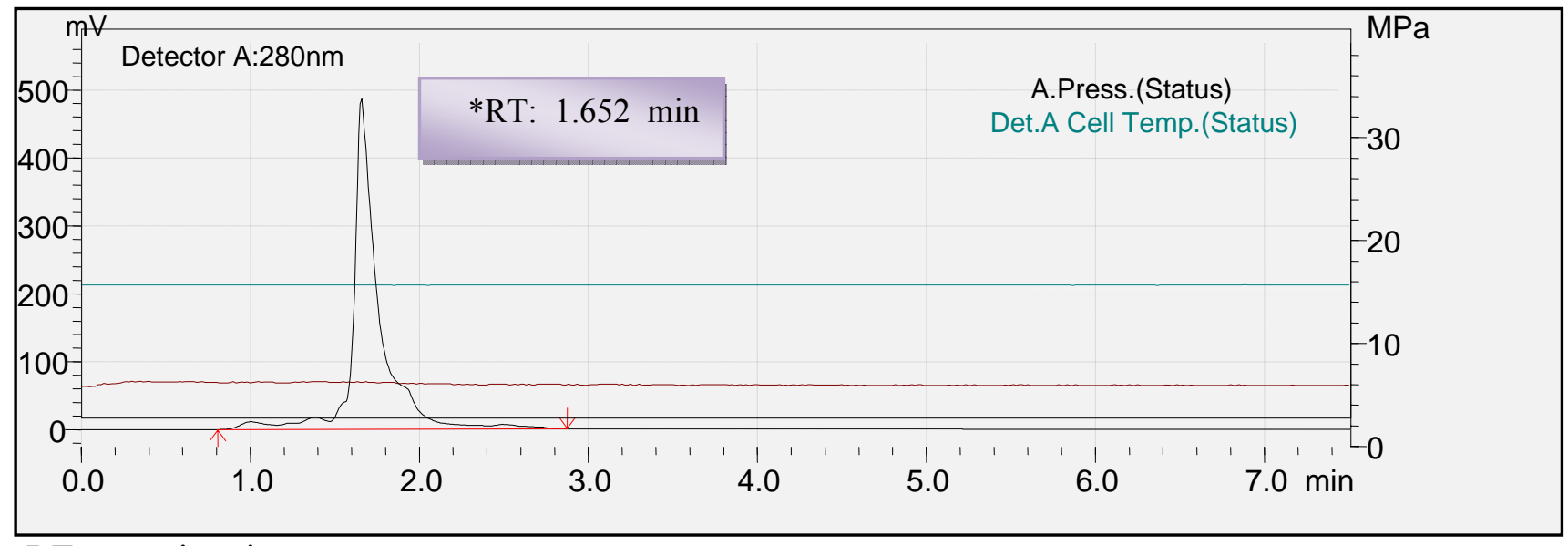

*RT: retention time

\section{Fig. 4: Chromatogram of sample (serum) solution (peak A) from gel filtration}

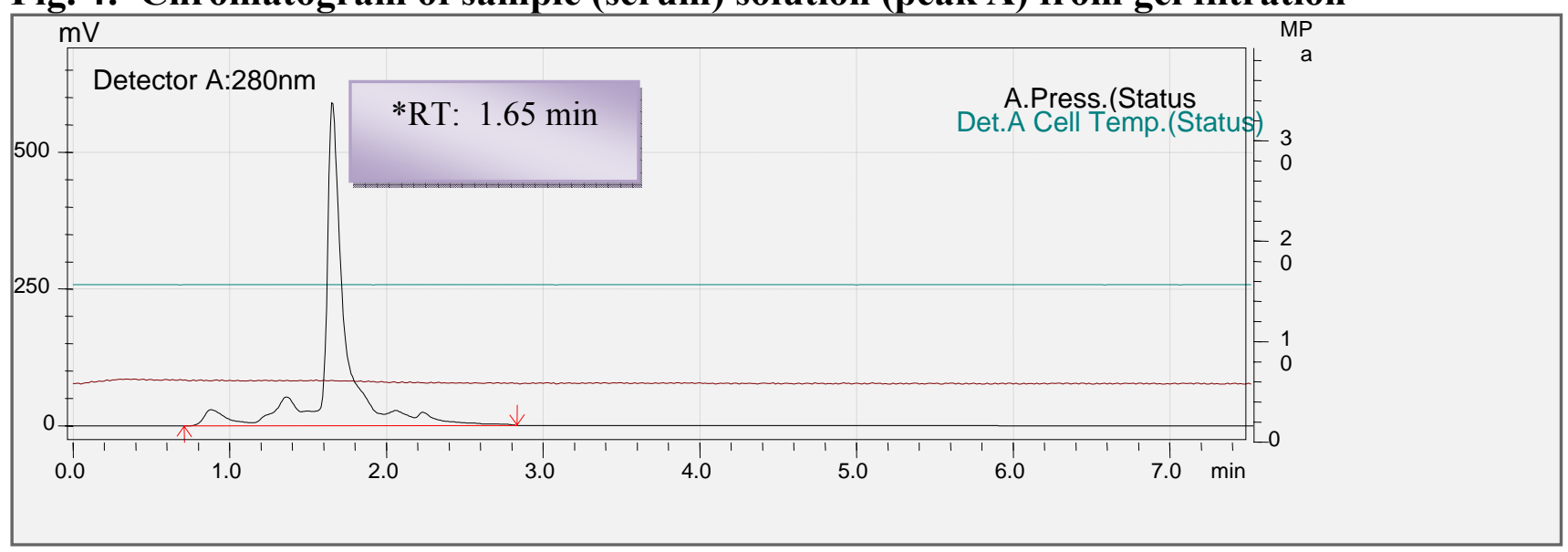

*RT: retention time

Fig. 5: Chromatogram of sample (synovial fluid) solution (peak A) from gel filtration 


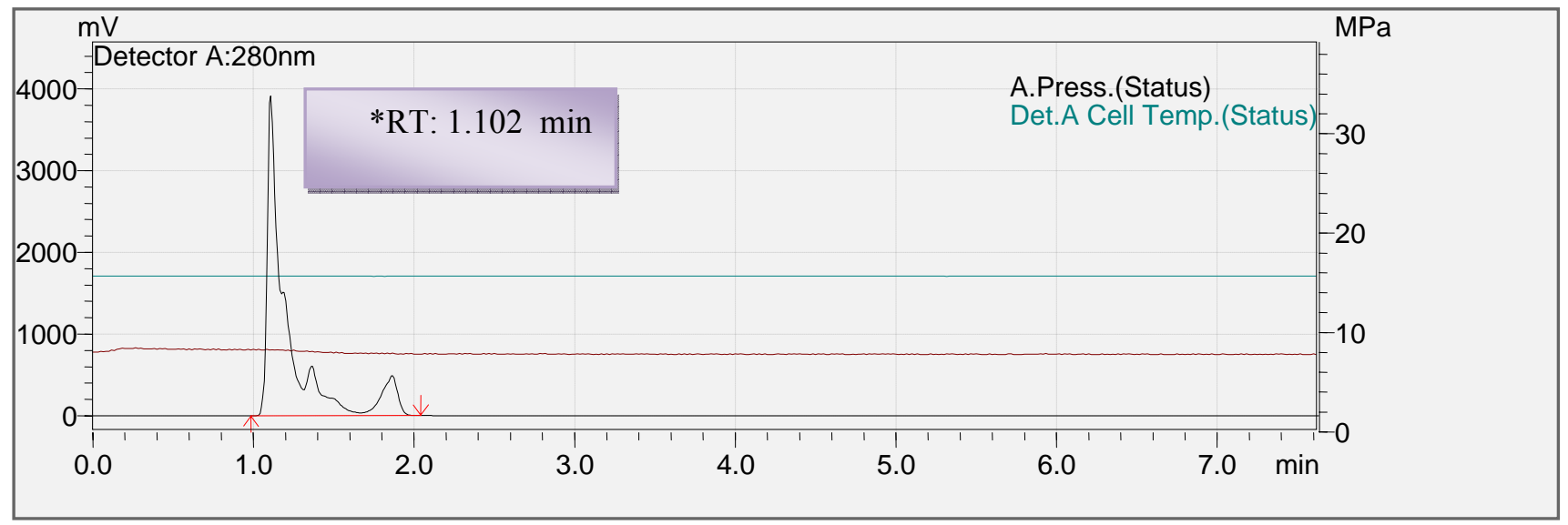

*RT: retention time

Fig. 6: Chromatogram of $\alpha$-amylase standard solution (M.Wt. $=58000$ dalton)

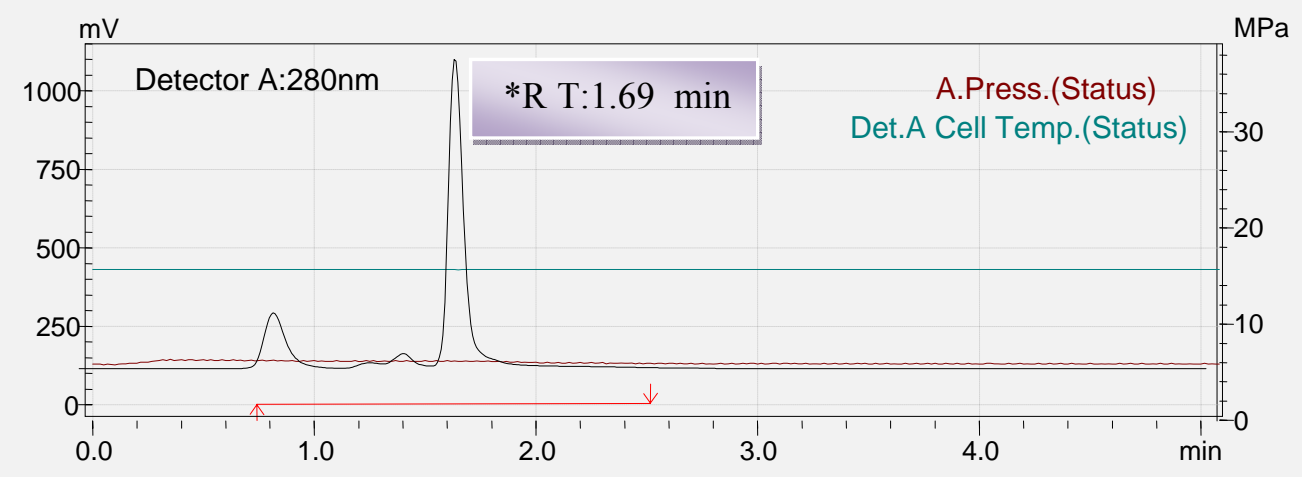

*RT: retention time

Fig. 7 : Chromatogram of egg albumin standard solution (M.Wt.=45000 dalton)

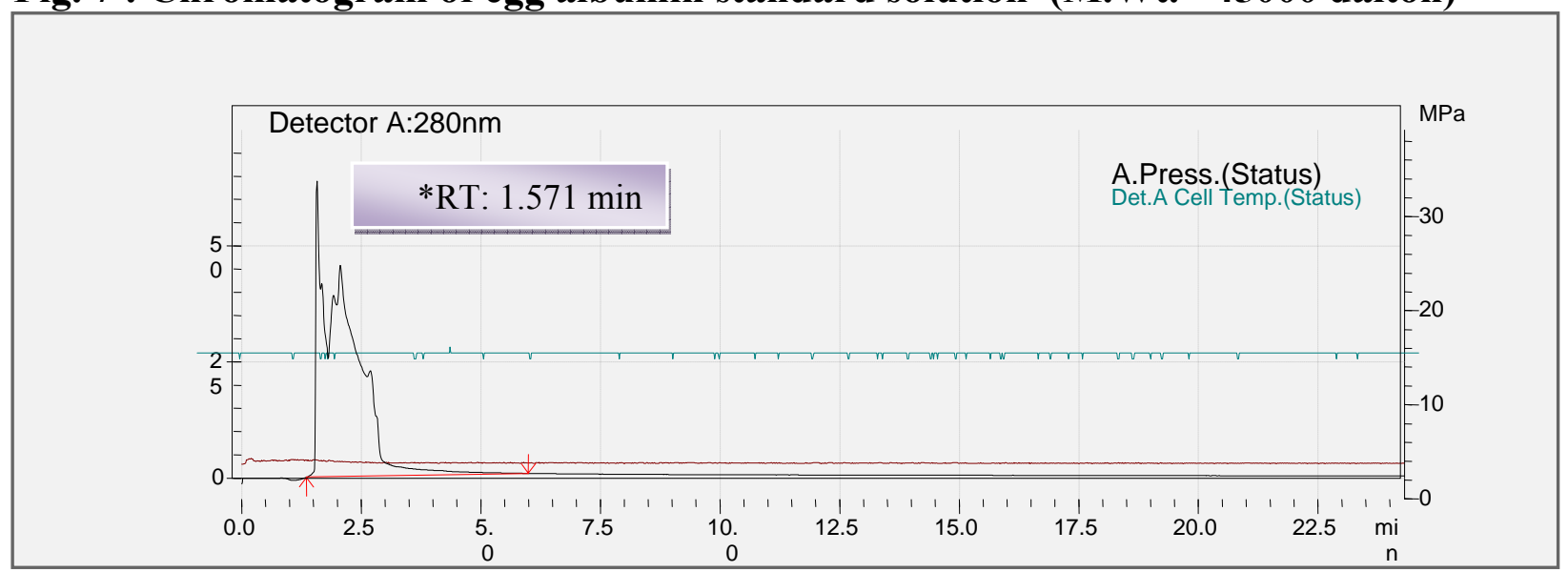

*RT: retention time

Fig. 8: Chromatogram of latent MMP-1 standard solution (M.Wt.= 53000 dalton) 


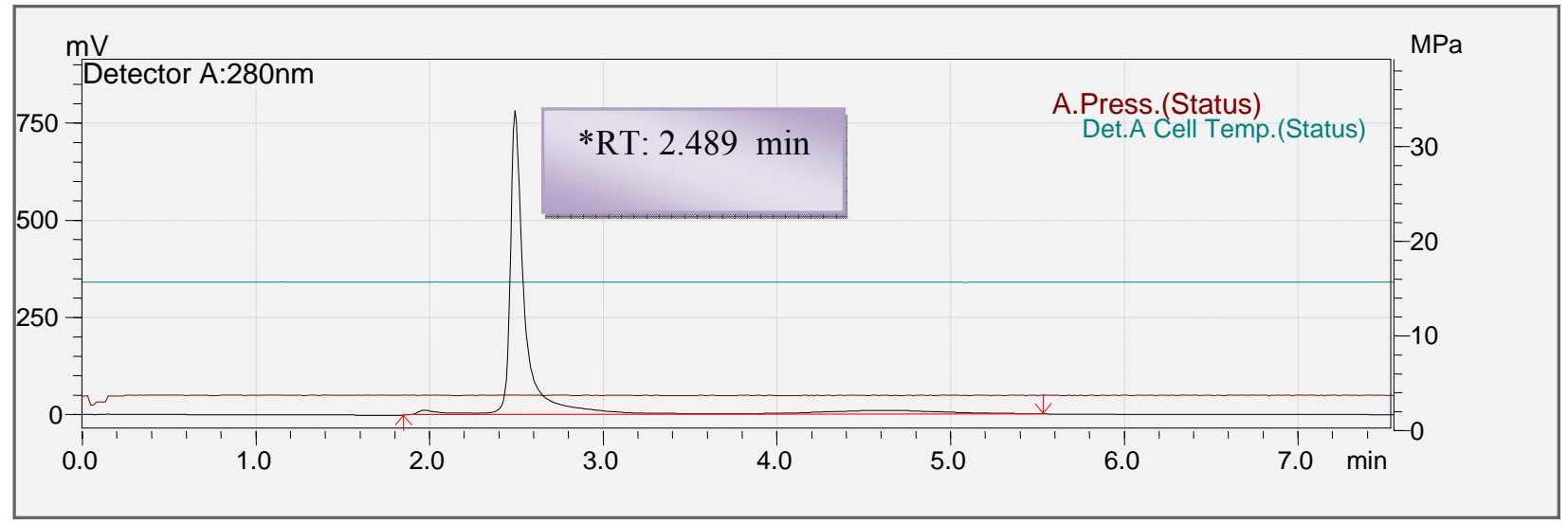

*RT: retention time

Fig. 9: Chromatogram of of pepsin standard solution (M.Wt.= 36000 dalton)

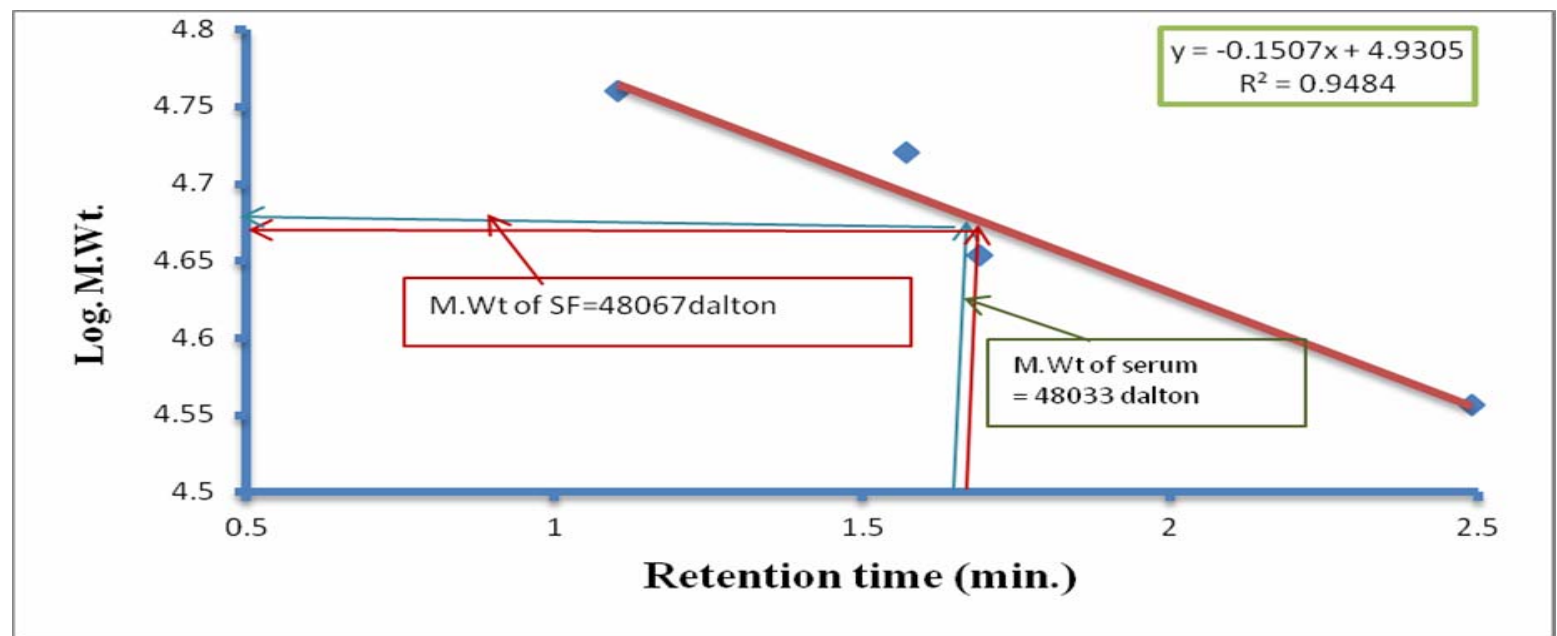

Fig. 10: Standard curve for determining the molecular weight (MWt.) of Latent-MMP-1 from serum and synovial fluid using using HPLC

\section{- The Effect of Various Material Compounds on Latent MMP-1 Activity}

In order to evaluate the effect of some material compounds on partially purified latentMMP-1 activity in vitro, series of experiments were performed and the results were listed in Table 4.

The results in Table (4) revealed that ethylene diamine tetra acetic acid (EDTA), 2, 4dintrophenol, sodium arsenate, sodium azide, potassium oxalate, mercaptoethanol (MEH), glutathion (GSH), cystein and normal human serum decrease latent-MMP-1 activity while $\mathrm{FeSO}_{4}, \mathrm{BaCl}_{2}$ and ascorbic acid showed no effect.

Metallo and serine collagenase require calcium, therefore, addition of EDTA and 2, 4dintrophenol leads to a decrease in the enzyme activity because EDTA acts as a chelating agent (Daboor et al., 2010; Hamdy, 2008; Swann et al., 1981; Fullmer et al., 1972; Hook et al., 1971). Moreover, the enzyme activity declined when cystein, GSH and sodium arsenate were added. This was attributed to that these compounds act specifically on disulfide bonds (Daboor et al., 2010; Hook et al., 1971). Mercaptoethanol (MEH) causes irreversible activation 
of enzyme activity by reduction of its thiol functional group (Hook et al., 1971). Also human serum causes a decline in enzyme activity, that $\alpha_{2}$-macroglobulin is a major serum protein, which makes divers functions included, inhibition of the collagenase activity and binding of growth factor, cytokines disease therefore adding serum to the partial purified causes decline enzyme activity (Vater et al., 1978).

On the other hand, addition some compounds to the partially purified enzyme (peak A) which were listed in Table 4 showed an increase in the enzyme activity. This could be explained to that the enzyme activity is depends on metal compounds such as $\mathrm{NaCl}, \mathrm{MgSO}_{4}$, $\mathrm{CaCl}_{2}, \mathrm{CoCl}_{2}, \mathrm{CuSO}_{4}$ and $\mathrm{ZnSO}_{4}$. Previous studies reported that the enzyme is dependant on $\mathrm{Ca}^{+2}$ and $\mathrm{Zn}^{+2}$. Also some investigators found that $\mathrm{Zn}^{+2}$ simulates and acts as a cofactor. As well as $\mathrm{Co}^{+2}$ level reversed activity action (Hamdy, 2008; Swann et al., 1981; Fullmer et al., 1972). Mercuric compounds such as $\mathrm{HgCl}_{2}$ causes dissociation of collagen-inhibitor complex, resulting in free enzyme. Pepsin also manifested the increase of the enzyme activity which might bind to an inhibitor protein such as $\alpha_{2}$-macroglubuline complex (Daboor et al., 2010).

Table 4: Effect of some material compounds on partially purified latent- MMP-1 activity in vitro from serum healthy and synovial fluid (SF) of rheumatoid arthritis (RA) patients

\begin{tabular}{|l|c|c|}
\hline Compound (10 mM) & $\begin{array}{c}\text { \% enzyme activity } \\
\text { in serum healthy }\end{array}$ & $\begin{array}{c}\text { \% enzyme activity } \\
\text { in SF of RA patient }\end{array}$ \\
\hline Pure enzyme & 100 & 100 \\
\hline EDTA & 64.8 & 43 \\
\hline 2-Mercaptoethanol(MEH) & 88.8 & 72.82 \\
\hline Cystein & 91.1 & 82.4 \\
\hline Glutathione(GSH) & 79.8 & 67 \\
\hline Sodium arsenate & 84.69 & 70.3 \\
\hline Normal human serum & 55.1 & 43 \\
\hline 2,4-Dinitrophenol & 87.9 & 73.1 \\
\hline Sodium azide & 81.5 & 80.6 \\
\hline Potassium oxalate & 84.14 & 72.3 \\
\hline FeSO & 103.6 \\
\hline $\mathrm{BaCl}_{2}$ & 101.3 & 102 \\
\hline $\mathrm{Ascorbic}$ acid & 99 & 108 \\
\hline pepsin & 102 & 113 \\
\hline $\mathrm{NaCl}$ & 120 & 117 \\
\hline $\mathrm{MgSO}_{4}$ & 114 & 133 \\
\hline $\mathrm{CaCl}_{2}$ & 125 & 140 \\
\hline $\mathrm{CoCl}_{2}$ & 135 & 119 \\
\hline $\mathrm{CuSO}_{4}$ & 113 & 122.2 \\
\hline $\mathrm{ZnSO}_{4}$ & 110 & 144 \\
\hline $\mathrm{HgCl}_{2}$ & 131 & 175 \\
\hline
\end{tabular}




\section{REFERENCES}

Aletaha, D.; Neogi, T.; Sliman, A.J. (2010). Rheumatoid arthritis classification criteria an American College of Rheumatology/European League Against Rheumatism collaborative initiative. Ann. Rheum. Dis., 69,1580-1588.

Andrews, P. (1965). The gel filtration behavior of proteins related to their molecular weight over a wide range. J. Biochem. 96, 595-606.

Arnett, F.C.; Edworthjy, S.M.; Bloch, D.A. (1988). The American Rheumatism Association 1987 revised criteria for the classification of rheumatoid arthritis. Arthritis. Rheum., 31, 315324.

Beurden, P.A.M.; Hoff, J.W. (2005). Zymographic techniques for the analysis of matrix metalloproteinases and their inhibitors. J. Bio. Techniques, 38(1), 73-83.

Carr, D. (2002). " The Handbook of Analysis and Purification of Peptides and Proteins by Reversed Phase HPLC". 3rd ed., Vydac, Hesperia, CA, USA. pp.30-39.

Chen, Y.; Nixon, N.B.; Dawes, P.T.; Mattey, D.L. (2012). Influence of variations across the MMP-1 and -3 genes on the serum levels of MMP-1 and -3 and disease activity in rheumatoid arthritis. Genes Immunity, 13 , 29- 37.

Daboor, S.; Buduge, S.M.; Ghaly, A.E.; Brooks, S.L.; Dave, D. (2010). Extraction and purification of collagenase enzymes. Acritical review. Am. J. Biochem. and Biotech,6 (4), 239-263.

Daboor, S.M.; Budge, S.M.; Ghaly, A.E.; Brooks, M.S.; Dave, D. (2012). Isolation and activation of collagenase from fish processing waste. Advances in Biosci. and Biotech., 3,191-203.

Dioxin, M.; Weeb, E.C. (1961). "Tools of Biochemistry". T.G. Copperol: 370. John Wiley and sons. Inc, $370 \mathrm{p}$.

Erdam, S.P.H.; Serdar, M.; Dinc, A.; Simsek, I.; Turan, M. (2002). Comparison of synovial MMP1 and TIMP-1 levels in patients with various inflammatory arthiritis: is there any difference between rheumatoid arthritis, behcet s disease and familial Mediterranean. Clin Rheumatol. 21, 511-515.

Fasciglione, G.F.; Gioia, M.; Tsukada, J.1.; Iundusi, R.; Tarantino, U.; Coletta, M.; Pourmotabbed, T.; Marini, S. (2012). The collagenolytic action of MMP-1 is regulated by the intraction between the catalytic domain and the hinge region. J. Biol. Inorg. Chem. 17, 663-672.

Fields, J.L.L.; Tuzinski, K.A.; Shimokawa, K.; Nagase, H. (2000). Hydrolysis of triple-helical collagen peptide models by matrix metalloproteinases. J. Biol. Chem., 275(18), 1328213290.

Fullmer, H.M.; Taylor, R.E.; Guthrie, R.W. (1972). Human gingival collagenase: purification, molecular weight and inhibitor studies. J. Dent. Supplement. 51, 349-355.

Hamdy, H.S. (2008). Extracellular collagenase from Rhizoctonia Solani: production, purification and characterization. Indian J. Biotechnol. 7, 333-340.

Holm, D.J. ; Peak, H. (1988). "Analytical Biochemistry". John Wiley and Sons, Inc., New York, USA.

Hook, C.W.; Brown, S.I.; Iwanij, W.; Nakanishi, I. (1971). Characterization and inhibition of corneal collagenase. Ophthalmol. Visual Sci. 10, 496-503.

Jain, R.; Jain P.C. (2010). Production and Partial characterization of collagenase of Streptomyces exfoliates CFS 1068 using poulry feather. Indian J. Experimental Biology. 48,174-178.

Kim, K.S. ; Choi, H.M.; Lee, Y.A.; Choi, I.A.; Lee, S.H. ; Hong, S.J.; Yang, H. I. ; Yoo, M. C. (2011). Expression of gelatinases MMP-2 and MMP-9 and colagenases MMP-1 and 
MMP-3 with VEGF in synovial fluid of patients with arthritis. Rheumatol Int., 31, 543547.

Leite, S. R. A. (2009). Inhibitors of collagenase, MMP1. Ecl. Quim., Sao Paulo, 34(4),187-102.

Maeda, S.; Sawai, T.; Uzuki, M.; Takahashi, Y.; Omoto, H.; Seki, M.; Sakurai M. (1995). Determination of interstitial collagenase (MMP-1) in patients with rheumatoid arthritis. Ann. Rheum. Dis., 54, 970-975.

Matsumoto, T.; Tsurumoto, T. (2006). Interleukin-6 levels in synovial fluids of patients with rheumatoid arthiritis correlated with the infiltration of inflammatory cells in synovial membrane. Rheumatol Int. 26, 1096-1100.

Peak, N.J.; Khawaja, K.; Myers, A.; Jones, D.; Cawston, T.E.; Rawan, A.D.; Foster, H.E. (2005). Levels of matrix metalloproteinase (MMP-1) in paired sera and synovial fluids of juvinale idiopathic arthiritis patients: relationship to inflammatory activity, MMP-3 and tissue inhibitor of metalloproteinases-1 in alongitudinal study. Rheumatology 44,1383-1389.

Philips, N.; Auler, S.; Hugo R. and Gonzalez S. (2011). Beneficial regulation of matrix metalloproteinases for skin healt. Enzyme Research, Review Articale. 10: 1-4.

Polyakova, V.; Loeffler, I.; Hein, S.; Miyagawa, S.; Piotrowska, I.; Dammer, S.; Risteli, J.; Schaper, J.; Kostin, S. (2011). Fibrosis in endstage human heart failure: severe changes in collagen metabolism and MMP/TIMP profiles. International J. Cardiology, 151,18-33.

Robyt , J.F.; White, B.J. (1987). "Biochemical Techniques Theory and Practice". Wads Worth Inc., Monterey, California, USA., pp. 235-236, 263, 269.

Sandya, S.; Achan, M.A.; Sudhakaran, P. R. (2009). Multiple matrix metalloproteinases in type II collagen induced arthritis. Indian J. Clinical Biochem., 24(1), 42-48.

Schacterle, G.R.; Pollack, R.L. (1973). A simplified method for the quantitative assay of small amounts of protein in biological material. Anal. Biochem., 51,654-655.

Sherer, S.; Souza, T.B.; Paoli, J.; Brenol, C.V.; Xavier, R.M.; Brenol, J.C.T.; Chies, J.A. (2010). Matrix metalloproteinase gene polymorphisms in patients with rheumatoid arthritis. Rheumatol INT., 30, 369-373.

Smith, Z.G.; Nagase, H.; Woessner, J.F. (1989). Purification of nutral proteoglycan-degrading metalloproteinase from human articular cartilage tissue and its identification as stromelysin matrix metallop roteinase-3 . J. Biochem. 258,115-119.

Swann, J.C.; Reynolds, J.J.; Galloway, W.A. (1981). Zinc metallo properties of active and latent collagenase from rabbit bone. J. Biochem.195, 41-49.

Tchetverikov, I.; Lohmander, L.S.; Verzijl, N.; Huizinga, T.W.J.; Tekoppele, J.M.; Hanemaaijer, R.; Degroot, J. (2005). MMP and activity levels in synovial fluid from patients with joint injury, inflammatory arthritis and osteoarthritis. Ann. Rheum. Dis, 64, 694-698.

Tietz, N.W. (1994). "Text Book of Clinical Chemistry". W. B. Sanders Company, USA, A. Division of Harcourt Brace and Company, Philadelpha.

Vater, C.A.; Mainardi, C.L.; Harris, E.D. (1978). Activation in vitro of rheumatoid collagens from cell cultures. J. Clin. Invest. 62, 987-992.

Yang, X.; Wang, Y. (2011). Role of siglecs on the leucocytes during the process of the joint's inflammation in rheumatoid arthritis. Medical Hypotheses, 77,1051-1053. 